\title{
ANAEROBIC TREATMENT OF SEWAGE SLUDGE AND GREASE TRAP SLUDGE IN CONTINUOUS CO-DIGESTION
}

\author{
E. NECZAJ ${ }^{*}$ \\ J. BIEN \\ A. GROSSER \\ M. WORWAG \\ M. KACPRZAK
}

Received: 07/12/11

Accepted: 09/03/12

\author{
Czestochowa University of Technology \\ Institute of Environmental Engineering \\ Bzeznicka 60a, 42-200 Czestochowa, Poland
}

\begin{abstract}
In recent years many researchers show a high interest in co-digestion, simultaneous anaerobic decomposition of a homogenous mixture of at least two biodegradable waste. Anaerobic codigestion is reported to offer several benefits over digestion of separate materials, such as increased cost-efficiency, increased biodegradation of the treated materials, as well as increased biogas production. Most often sewage sludge is digested alone while co-digestion with other substrates could be beneficial.

In this study, the feasibility of co-digestion sewage sludge and grease trap waste (GTW) from meatprocessing plant was investigated in lab-scale reactor experiment. The research was made on the sewage sludge coming from municipal wastewater treatment plant and grease trap waste coming from meat industry company. Anaerobic co-digestion was studied in semi-continuous experiment at $37^{\circ} \mathrm{C}$. Feeding of reactors was performed once a day with hydraulic retention time (HRT) of 10 days. The grease trap waste accounted for 2, 4, 6, 8 and $10 \%$ of the mixture on the volatile solids basis. The mixtures were analyzed for the following parameters: total solids, volatile solids, $\mathrm{pH}$, volatile fatty acids and long chain fatty acids (LCFAs). The control of digestion process was made every day on the basis of the measurement of the biogas production. What is more, there was determined the volatile solid removal as well the biogas yield in order to assess the efficiency of co-digestion process.

It was found that co-digestion of sewage sludge and grease trap waste improved both biogas production and methane content. Grease trap waste addition of $10 \%$ of feed VS increased the biogas production by $16 \%$ as well as methane concentration (72\% of biogas) compared to the period when reactor was feed only with sewage sludge. Moreover, the addition of GTW to the anaerobic digestion of sewage sludge increased organic matter removal.

Although, the significant variations in LCFAs reduction, the biogas production and methane yield increased with higher addition of GTW.

The results of the present laboratory study revealed that the use of GTW as a co-substrate is considered to be interesting option for sewage sludge digestion due to increased methane production. However, the feed should be planned carefully with stepwise increase to the desired feed ratio in order to acclimatize the bacteria and to prevent reactor overloading.
\end{abstract}

KEYWORDS: co-digestion, sewage sludge, grease trap waste, long chain fatty acids.

\section{INTRODUCTION}

Co-digestion has been defined as the anaerobic treatment of a mixture at least two different substrates with the aim of improving the efficiency of the anaerobic digestion process. Anaerobic codigestion is reported to offer several benefits over digestion of separate materials, such as increased cost-efficiency, increased biodegradation of the treated materials, as well as increased biogas production. There is abundant literature about the utilization of co-digestion, such as co-digestion of 
organic fraction of municipal solid waste (OFMSW) and agricultural residues, organic solid wastes and sewage sludge or more specific wastes. Most often sewage sludge is digested alone while codigestion with other substrates could be beneficial. Co-digestion of different substrates and sewage sludge could be beneficial due to dilution of inhibitive substances, improved nutrient content (ammonium nitrogen, potassium, phosphorus, calcium, magnesium) and synergistic effect between the treated materials resulting in better degradation of both (Malta-Alvarez et al., 2000). While anaerobic co-digestion has been studied and practiced for a broad range of organic wastes, few studies have been conducted on the co-digestion of municipal waste sludge (MWS) with grease trap waste (GTW) as a co-substrate. Grease trap waste comprises of greasy materials separated from wastewater. GTW is an animal by-product (ABP) when produced in meat processing plants. Therefore hygienization treatment is required for ABPs (1069/2009) to eliminate pathogens from the treated material.

The primary components of GTW are essentially spent fat, oil and grease with associated solids and debris. Treatment of GTW in conventional aerobic processes presents a challenge to wastewater treatment facilities mainly because of its slow biodegradation kinetics, high oxygen demand, and risks of pipeline blockage. The use of GTW alone as a substrate for anaerobic treatment also remains difficult with large variations in waste characteristic and inhibitory effects due to high lipids content. Thus, co-digestion with sewage sludge offers the most attractive possibility.

The GTW contain remarkable amount of grease, with a high methane potential; however its degradation products (long chain fatty acids) could inhibit the process when a high concentration is presented (Luste et al., 2008). During fermentation process lipids are initially hydrolyzed to glycerol and long chain fatty acids (LCFAs), which are further converted to hydrogen and acetate, and finally to methane. The degradation of LCFAs take place through $\beta$-oxidation pathway, which has been reported as the rate-limiting step of whole anaerobic digestion process (Lalman and Bagely, 2000). The effect of LCFAs on the methanogenic and acetogenic microorganisms are widely documented (Hanaki et al., 1981; Koster and Cramer, 1987, Rinzema et al., 1994). The inhibitory effect is known to both syntrophic acetogenes and methanogenes, although acetoclastic methanogenes are apparently more affected by the presence of LCFAs (Hwu et al., 1998). Adsorption of LCFAs onto the microbial surface has been suggested as the mechanism of inhibition due to influence on the transport of nutrients into the cell (Pereira et al., 2005). However many authors showed that inhibition by LCFAs is not permanent and the adaptation of microorganisms to lipids can occur (Broughton et al, 1998; Alves et al., 2001; Pereira et al., 2004; Nielsen and Ahring, 2006; Palatsi et al., 2009). It is not clear whether this adaptation process is the results of population adaptation or physiological acclimatation.

In this study, the feasibility of co-digestion sewage sludge and grease trap waste from meatprocessing plant was investigated in lab-scale reactor experiment at $37^{\circ} \mathrm{C}$.

\section{MATERIALS AND METHODS}

\subsection{Materials}

Sewage sludge and inoculum (digested sewage sludge) for all experiments were obtained from municipal wastewater treatment plant (Silesian Region, Poland). Grease trap waste was from a meat processing plant (Silesian Region, Poland) specializing in meat cutting (cows and pigs) and production of different meat products. The GTW was frozen at $-25^{\circ} \mathrm{C}$ during experiment period in a laboratory freezer and thawed before use. Co-digestion mixture was stored in plastic buckets, and kept at $4^{0} \mathrm{C}$ prior to use. Feed mixtures of sewage sludge and grease trap waste were prepared daily. The co-substrates were completely mixed by a motor driven mixer for 30 s before feeding. To evaluate the potential of GTW as a co-substrate for the anaerobic of sewage sludge, the characteristic of GTW were analyzed and compared to those sewage sludge, co-substrates mixtures as well as the inoculums material (Table 1). The GTW was characterized by a high organic matter concentration compared to sewage sludge.

Oleic, palmitic and stearic acids were the most abundant LCFAs in GTW, representing 53\%, 29\% and $16 \%$ of the total long chain fatty acids, respectively (Table 2). Myristic and arachidic acids were also present in minor quantities. 
Table 1. Characteristics of raw substrates and co-substrates mixtures used in the study

\begin{tabular}{c|c|c|c|c|c}
\hline \multicolumn{2}{c}{ Sludge } & $\begin{array}{c}\text { Percentage of } \\
\text { VS in feed }\end{array}$ & $\begin{array}{c}\text { TS } \\
\text { (\%) }\end{array}$ & $\begin{array}{c}\text { VS } \\
\text { (\%) }\end{array}$ & \multicolumn{2}{c}{ VS/TS } & pH \\
\hline Inoculum & - & 2.84 & 1.6 & 0.56 & 9.51 \\
\hline Sewage sludge & - & $2.38-4.51$ & $1.84-3.5$ & $0.66-0.77$ & $6.02-7.11$ \\
\hline Grease trap sludge & - & 37.38 & 36.54 & 0.98 & 5.23 \\
\hline Feed 1 & 2 & 3.19 & 2.42 & 0.76 & 6.29 \\
\hline Feed 2 & 4 & 3.19 & 2.41 & 0.76 & 6.28 \\
\hline Feed 3 & 6 & 2.53 & 1.99 & 0.78 & 6.5 \\
\hline Feed 4 & 8 & 2.6 & 2.07 & 0.79 & 6.81 \\
\hline Feed 5 & 10 & $3.22-3.79$ & $2.54-2.98$ & $0.78-0.79$ & $5.8-6.59$ \\
\hline
\end{tabular}

Table 2. Concentration of long chain fatty acids in substrates and co-substrates mixtures

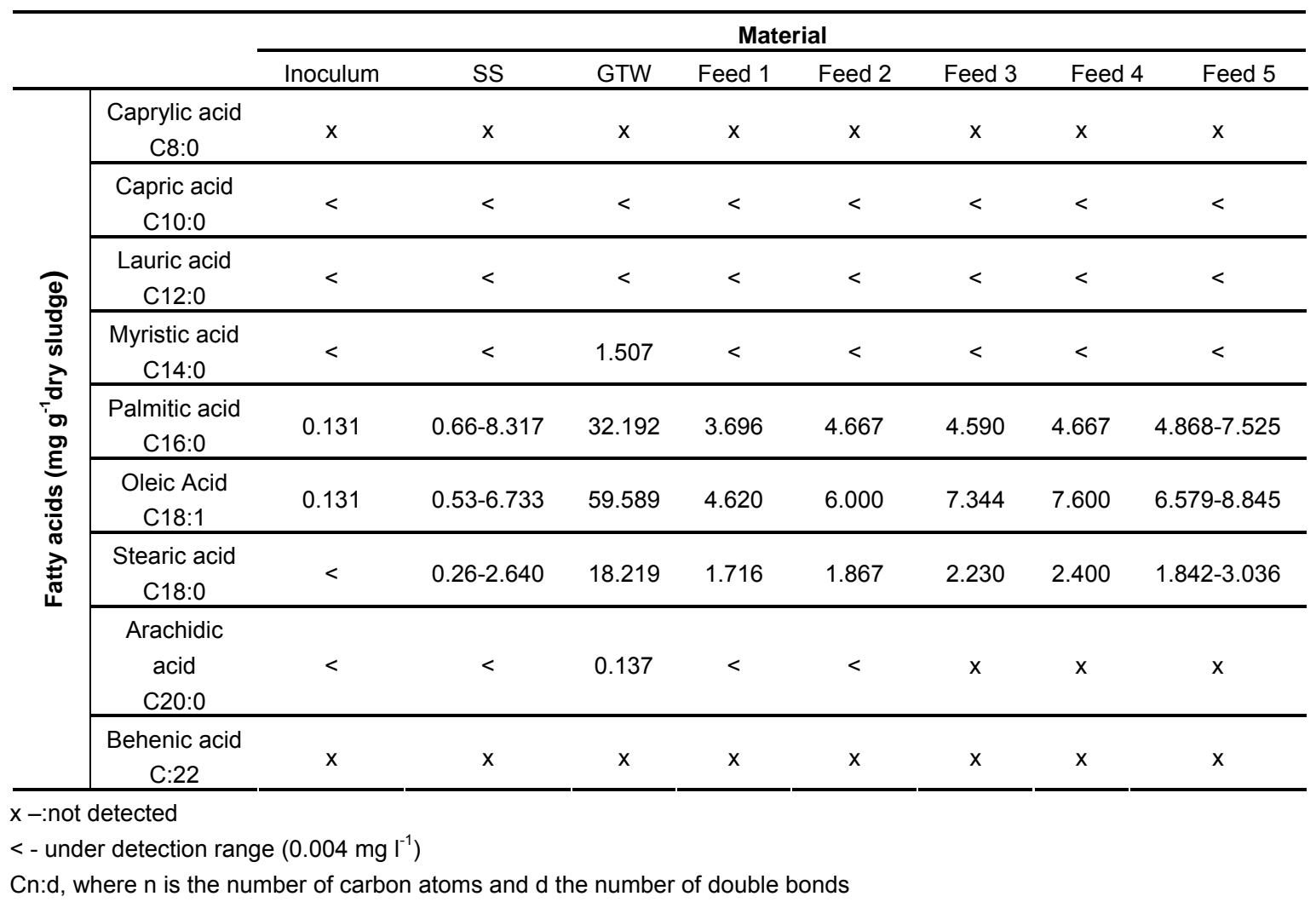

\subsection{Reactor experiment}

Reactor experiment was conducted in a glass reactor with a liquid volume of $5.5 \mathrm{I}$ at $37^{\circ} \mathrm{C}$ with constant mixing at $180 \mathrm{rpm}$ by a mechanical stirrer (Figure 1). The temperature was controlled by a thermostatically regulated water bath. Biogas exited at the top of the reactor via tube for gas sampling. The rector was connected to PVC tube filled with water acidified to $\mathrm{pH} 3$ and biogas was collected by displacement of water. The reactor was operated in draw-and fill mode (on a daily basis) with retention time of 10 days. Initially the reactor was inoculated with anaerobic sludge from WWTP. The digester operated with a sewage sludge as a feed during 30 days.

In a second part of experiment reactor was fed with mixture of sewage sludge and grease trap waste. The grease trap waste accounted for 2, 4, 6, 8 and $10 \%$ of the mixture on the volatile solids (VS) basis.

\subsection{Analytical methods}

Total solids (TS), volatile solids (VS), $\mathrm{pH}$ ( $\mathrm{pH}$ meter Cole Parmer Model No. 59002-00), alkalinity and total volatile acids (VFAs) (steam distillation - BÜCHI K-355) were determined according to APHA (1999) standard methods. 


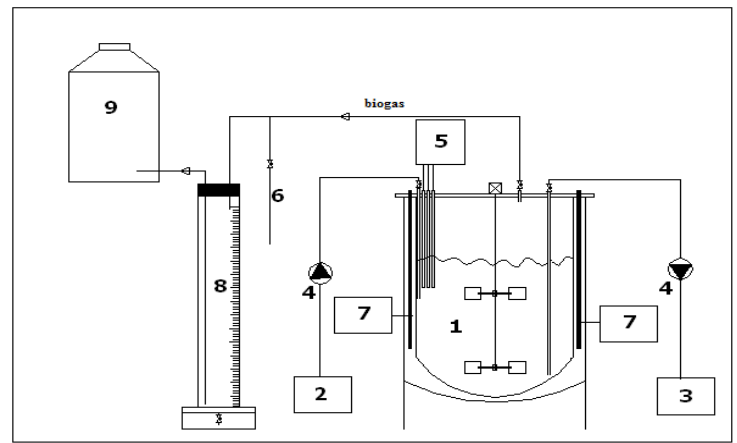

Figure 1. Digester set-up: (1) reactor with mechanical stirrer, (2) influent, (3) effluent, (4) pump (5) $\mathrm{pH}$, redox meter, (6) gas sampling port, (7) heating jacket, $(8,9)$ gas flow measurement

Biogas production was measured each day by the liquid displacement method (acidified saturated $\mathrm{NaCl}$ ) and the methane percent in biogas was analyzed in a portable gas analyzer (GA 2000, Geotechnical Instruments (UK) Ltd.). All gas results are calculated at standard temperature and pressure.

LCFAs (caprylic (C:8), capric (C:10), lauric (C12:0), myristic (C14:0), palmitic (C16:0), stearic (C18:0), oleic (C18:1), arachidic (C:20) and behenic (C22:0) acids) analyses were performed according to Casado et al., 1998 with some modifications made by the_authors (external standard, volume of methanol and the order of addition of the reagents). Quantification was made in a Thermo Scientific GCMS system equipped with Rxi-5ms (Restek) fused-silica capillary (30 m x $0.25 \mathrm{~mm}$ diameter and $0.25 \mu \mathrm{m}$ film thickness) and MS detector (injector $200^{\circ} \mathrm{C}$, oven $240^{\circ} \mathrm{C}$ with increase of $10^{0} \mathrm{C}$, carrier gas helium $2 \mathrm{ml} \mathrm{min}^{-1}$ ).

\section{RESULTS AND DISCUSION}

After 10 days of batch assays, the reactor was feed with sewage sludge at low concentration (TS 2.8\%) maintain organic loading rate (OLR) of around $2.2 \mathrm{~g} \mathrm{VS}^{-1} \mathrm{~d}^{-1}$ (Table 3 ). The low reduction in VS (average $44 \%$ ), as well as high values of VFA in the beginning of that period are related to the acclimation of microorganisms during the start-up period (Ahring, 1994). The concentration of VFA has been found to be a very good indicator of the metabolic status of anaerobic degradation process (Fernandez et al., 2005). An initial increase of VFA is typical for start-up of anaerobic process when the balance of the hydrolytic bacteria, fermentative bacteria and methanogenes has not stabilized yet (Hartmann and Ahring, 2005). During the next stages the concentration of VFAs gradually declined as did the $\mathrm{pH}$.

One of the criteria for evaluation of digester stability is the VFA:alkalinity ratio. There are three critical values for this (Callaghan et al., 2002): <0.4 digester should be stable; 0.4-0.8 some instability will occur; $>0.8$ significant instability of digester. At the beginning of the process, when the sewage sludge was being digested alone (days 10-40), the ratio was in the 0.3-0.6 range. When GTW was being added to the feed, the VFA:alkalinity ratio did not rise above the critical value of 0.4 . Moreover, N-NH ${ }_{4}^{+}$concentration decreased in the effluent up to $500 \mathrm{mg} \mathrm{L}^{-1}$ for $8 \% \mathrm{GTW}$ addition and next increased slowly for higher waste dose (Figure 2).

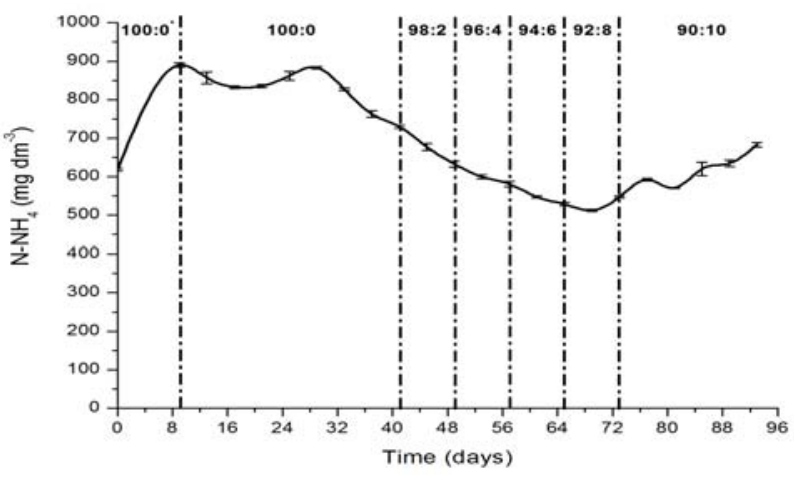

Figure 2. Variation of ammonium nitrogen concentration in the effluent in co-digestion 
The average values of the methane production in co-digestion experiment are presented in Table 4. Daily biogas production by digestion of sewage sludge alone and the co-digested wastes varied between $6.006 \mathrm{~L} \mathrm{~d}^{-1}$ and $9.045 \mathrm{~L} \mathrm{~d}^{-1}$ depending to the substrate composition. Co-digestion of sewage sludge and grease trap waste improved both biogas production and methane content.

Table 3. Characteristics of the digested material during fermentation of sewage sludge and codigestion of sewage sludge and grease trap sludge

\begin{tabular}{|c|c|c|c|c|c|c|c|}
\hline Day & $\begin{array}{c}\text { Grease } \\
\text { addition } \\
\text { (\% of VS) }\end{array}$ & $\begin{array}{l}\text { TS } \\
(\%) \\
\end{array}$ & $\begin{array}{l}\text { VS } \\
(\%) \\
\end{array}$ & VS/TS & $\begin{array}{c}\text { Total VFA } \\
\left(\mathrm{mg} \mathrm{l}^{-1}\right)\end{array}$ & $\begin{array}{c}\text { VFAl } \\
\text { Alkalinity }\end{array}$ & $\mathrm{pH}$ \\
\hline \multirow{7}{*}{$10-40$} & \multirow{7}{*}{-} & $2.62 \pm 0.04$ & $1.62 \pm 0.03$ & 0.618 & $2320 \pm 86$ & 0.5954 & 8.63 \\
\hline & & $2.88 \pm 0.02$ & $1.72 \pm 0.01$ & 0.599 & $1257 \pm 40$ & 0.3202 & 8.67 \\
\hline & & $2.77 \pm 0.02$ & $1.73 \pm 0.01$ & 0.625 & $1520 \pm 65$ & 0.3832 & 9.11 \\
\hline & & $2.83 \pm 0.02$ & $1.75 \pm 0.01$ & 0.619 & $1120 \pm 43$ & 0.2763 & 9.02 \\
\hline & & $2.64 \pm 0.007$ & $1.70 \pm 0.01$ & 0.645 & $1246 \pm 150$ & 0.3089 & 8.83 \\
\hline & & $2.43 \pm 0.01$ & $1.62 \pm 0.01$ & 0.666 & $989 \pm 88$ & 0.2669 & 8.92 \\
\hline & & $2.38 \pm 0.02$ & $1.58 \pm 0.01$ & 0.666 & $880 \pm 40$ & 0.2519 & 8.62 \\
\hline \multirow{2}{*}{$41-48$} & \multirow{2}{*}{2} & $2.33 \pm 0.02$ & $1.54 \pm 0.01$ & 0.663 & $897 \pm 77$ & 0.2665 & 8.47 \\
\hline & & $2.15 \pm 0.01$ & $1.41 \pm 0.01$ & 0.654 & $840 \pm 17$ & 0.2551 & 8.65 \\
\hline \multirow{2}{*}{$49-56$} & \multirow{2}{*}{4} & $2.07 \pm 0.01$ & $1.34 \pm 0.01$ & 0.645 & $800 \pm 55$ & 0.2603 & 8.04 \\
\hline & & $2.01 \pm 0.01$ & $1.29 \pm 0.01$ & 0.642 & $874 \pm 34$ & 0.2879 & 7.96 \\
\hline \multirow{2}{*}{$57-64$} & \multirow{2}{*}{6} & $1.99 \pm 0.02$ & $1.27 \pm 0.01$ & 0.640 & $600 \pm 17$ & 0.2034 & 7.99 \\
\hline & & $1.85 \pm 0.03$ & $1.20 \pm 0.02$ & 0.645 & $606 \pm 20$ & 0.2153 & 7.92 \\
\hline \multirow{2}{*}{$65-72$} & \multirow{2}{*}{8} & $1.74 \pm 0.02$ & $1.14 \pm 0.01$ & 0.651 & $640 \pm 26$ & 0.2406 & 7.99 \\
\hline & & $1.69 \pm 0.02$ & $1.07 \pm 0.005$ & 0.636 & $577 \pm 36$ & 0.2194 & 7.85 \\
\hline \multirow{2}{*}{$73-80$} & \multirow{2}{*}{10} & $1.75 \pm 0.03$ & $1.13 \pm 0.02$ & 0.644 & $611 \pm 10$ & 0.2346 & 7.86 \\
\hline & & $1.75 \pm 0.02$ & $1.13 \pm 0.01$ & 0.648 & $571 \pm 26$ & 0.2127 & 7.98 \\
\hline \multirow{2}{*}{ 81-88 } & \multirow{2}{*}{10} & $1.76 \pm 0.02$ & $1.15 \pm 0.02$ & 0.654 & $560 \pm 38$ & 0.2173 & 8.00 \\
\hline & & $1.77 \pm 0.02$ & $1.16 \pm 0.01$ & 0.657 & $704 \pm 58$ & 0.2579 & 7.82 \\
\hline \multirow{2}{*}{$89-96$} & \multirow{2}{*}{10} & $1.90 \pm 0.04$ & $1.26 \pm 0.03$ & 0.664 & $629 \pm 36$ & 0.2102 & 7.70 \\
\hline & & $2.05 \pm 0.02$ & $1.35 \pm 0.01$ & 0.656 & $617 \pm 34$ & 0.2053 & 7.72 \\
\hline
\end{tabular}

Table 4. Average biogas and methane production during co-digestion process

\begin{tabular}{ccccc}
\hline Day & $\begin{array}{c}\text { Grease addition } \\
\text { (\% of VS) }\end{array}$ & $\begin{array}{c}\text { Biogas } \\
\left(\mathbf{I ~ d}^{-1}\right)\end{array}$ & $\begin{array}{c}\text { Methane } \\
\left(\mathbf{I ~ d ~}^{-1}\right)\end{array}$ & $\begin{array}{c}\text { Methane } \\
(\%)\end{array}$ \\
\hline $\mathbf{1 0 - 4 0}$ & - & $7.780 \pm 1.163$ & $5.422 \pm 0.860$ & $69.63 \pm 1.96$ \\
\hline $\mathbf{4 1 - 4 8}$ & 2 & $6.734 \pm 0.179$ & $4.749 \pm 0.080$ & $70.55 \pm 0.99$ \\
\hline $\mathbf{4 9 - 5 6}$ & 4 & $6.850 \pm 0.138$ & $4.846 \pm 0.078$ & $70.75 \pm 0.41$ \\
\hline $\mathbf{5 7 - 6 4}$ & 6 & $6.313 \pm 0.119$ & $4.491 \pm 0.096$ & $71.15 \pm 0.74$ \\
\hline $\mathbf{6 5 - 7 2}$ & 8 & $6.006 \pm 0.119$ & $4.292 \pm 0.0595$ & $71.475 \pm 1.09$ \\
\hline $\mathbf{7 3 - 8 0}$ & 10 & $7.935 \pm 0.297$ & $5.724 \pm 0.204$ & $72.14 \pm 0.3$ \\
\hline $\mathbf{8 1 - 8 8}$ & 10 & $7.739 \pm 0.235$ & $5.632 \pm 0.198$ & $72.59 \pm 0.57$ \\
\hline $\mathbf{8 9 - 9 6}$ & 10 & $9.045 \pm 0.354$ & $6.545 \pm 0.254$ & $72.48 \pm 0.5$ \\
\hline
\end{tabular}

The highest daily methane production was 9 I d $\mathrm{d}^{-1}$ obtained for the last stage (days 89-96). Grease trap waste addition of $10 \%$ of feed VS increased the biogas production by $16 \%$ as well as methane concentration (72\% of biogas) compared to the period when reactor was feed only with sewage sludge.

Methane production potential of GTW is higher and accordingly, methane yield during the codigestion was increased as compared to digesting sewage sludge alone (Figure 3). Variation of biogas yield was due to fluctuation in OLR caused by changing of VS content in sewage sludge.

Still, in comparison with the results of Davidsson et al. (2008) and Luostarinen et al. (2009) (see Table 5) specific methane yield from sewage sludge as well as VS reduction was presently lower in spite of lower OLR. Adding 10\% grease trap waste on VS basis, specific methane yield increased by 
$9-14 \%$ in Davidson et al. (2008) and by $14 \div 16 \%$ in the present study. VS removal were approximately $55 \%$ in both. The difference could be explained by different HRT as well as study scale. Because Davidsson et al. (2008) worked in pilot scale, a full scale experiment should be performed in order to verify the present results. Likewise, Luostarinen et al. (2009) adding 5\% grease trap waste reported specific methane yield increase by $35 \%$ and higher VS reduction.

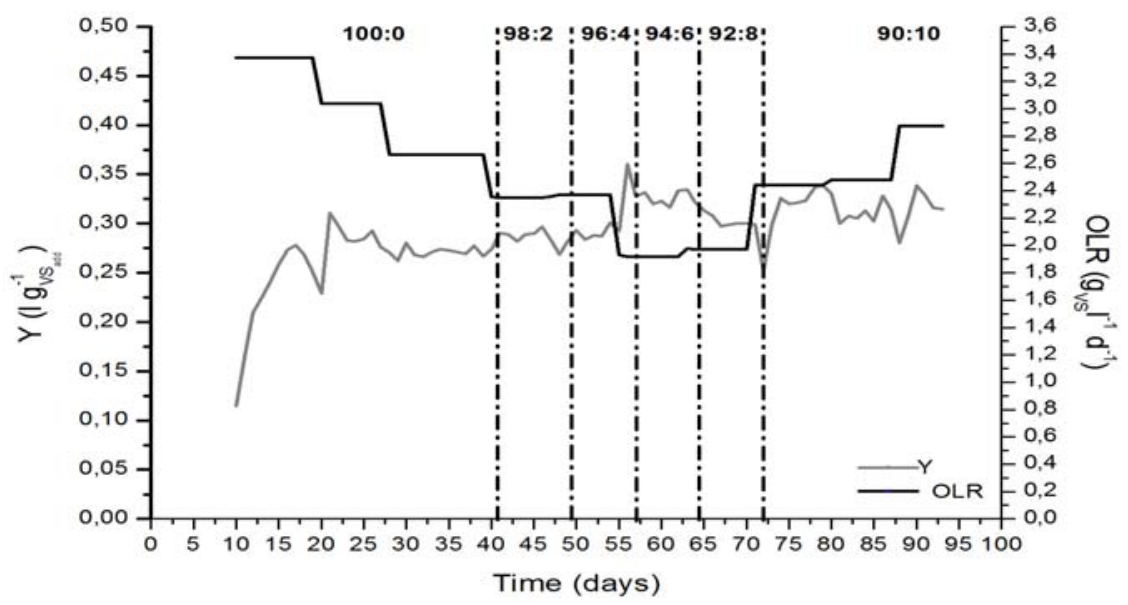

Figure 3. Evaluation of biogas yield and OLR in the semi-continuous lab-scale reactor experiment

Table 5. Comparison of results from the present study and Luostarinen et al. (2009)

and Davidsson et al. (2008)

\begin{tabular}{|c|c|c|c|c|c|}
\hline Study & $\begin{array}{l}\text { Digested } \\
\text { sludge } \\
\text { types }^{*}\end{array}$ & $\begin{array}{l}\text { Methane yield } \\
{\left[\mathrm{m}^{3} \mathrm{Mg}^{-1} \mathrm{VS}_{\mathrm{add}}\right]}\end{array}$ & $\begin{array}{l}\mathrm{CH}_{4} \\
{[\%]} \\
\end{array}$ & $\begin{array}{c}\text { VS } \\
\text { reduction } \\
{[\%]} \\
\end{array}$ & $\begin{array}{c}\text { OLR } \\
{\left[\mathrm{kgVS} \mathrm{m}^{-3} \cdot \mathrm{d}^{-1}\right]}\end{array}$ \\
\hline \multirow[t]{6}{*}{ Present study } & $100: 0$ & 181 & 69.63 & 44.38 & $2.66-3.37$ \\
\hline & $98: 2$ & 202 & 70.55 & 38.92 & 2.35 \\
\hline & $96: 4$ & 211 & 70.75 & 45.51 & 2.36 \\
\hline & $94: 6$ & 232 & 71.15 & 37.66 & 1.93 \\
\hline & $92: 8$ & 212 & 71.475 & 45.70 & 1.98 \\
\hline & $90: 10$ & 229 & 72.42 & 55.14 & $2.44-2.87$ \\
\hline \multirow{8}{*}{$\begin{array}{l}\text { Luostarinen et al. } \\
\qquad(2009)\end{array}$} & $100: 0$ & 278 & 63 & 52 & $1.56-2.09$ \\
\hline & $95: 5$ & 374 & 66 & 59 & $1.67-2.23$ \\
\hline & $80: 20$ & 441 & 64 & 58 & $1.93-2.45$ \\
\hline & $72: 28$ & 444 & 61 & 52 & 2.8 \\
\hline & $62: 38$ & 447 & 65 & 64 & 3.13 \\
\hline & $54: 46$ & 463 & 62 & 67 & 3.46 \\
\hline & $45: 55$ & 318 & 63 & 72 & 3.99 \\
\hline & $29: 71$ & 315 & 58 & 70 & 4.41 \\
\hline \multirow{3}{*}{$\begin{array}{c}\text { Davidsson et al. } \\
(2008)\end{array}$} & $100: 0$ & 271 & 65 & 45 & 2.5 \\
\hline & $90: 10$ & 295-308 & 66 & 55 & 2.5 \\
\hline & $70: 30$ & 344 & 69 & 58 & 2.4 \\
\hline
\end{tabular}

*Mixing ratio SS: GS (\% of VS)

Figure 4 presents the evolution of the LCFAs in the effluent during co-digestion process. Palmitic acid was the most abundant LCFAs in the period studied, and the similar concentration profile was observed for oleic acid. The concentration of stearic acid was always lower. During batch assay (days 1-10) the concentration of LCFAs significantly decreased. The lowers LCFAs concentration was observed on day 50. Then there was significant increase in this acids concentration up to 66 day as well as significant decrease of LCFAs removal efficiency (see Figure 5) due to high LCFAs content in feed. During next few days LCFAs in effluent slightly dropped which correlated with those better removal in anaerobic process. Between days 78 and 82 LCFAs increased significantly while removal efficiency decreased to the lowers level of the studied period, about $10 \%$ for $\mathrm{C} 16: 0$ and $\mathrm{C}$ 
18:0 and under $65 \%$ for C 18:1, respectively. During the next day LCFAs decreased which correlated with lower acids concentration in the effluent.

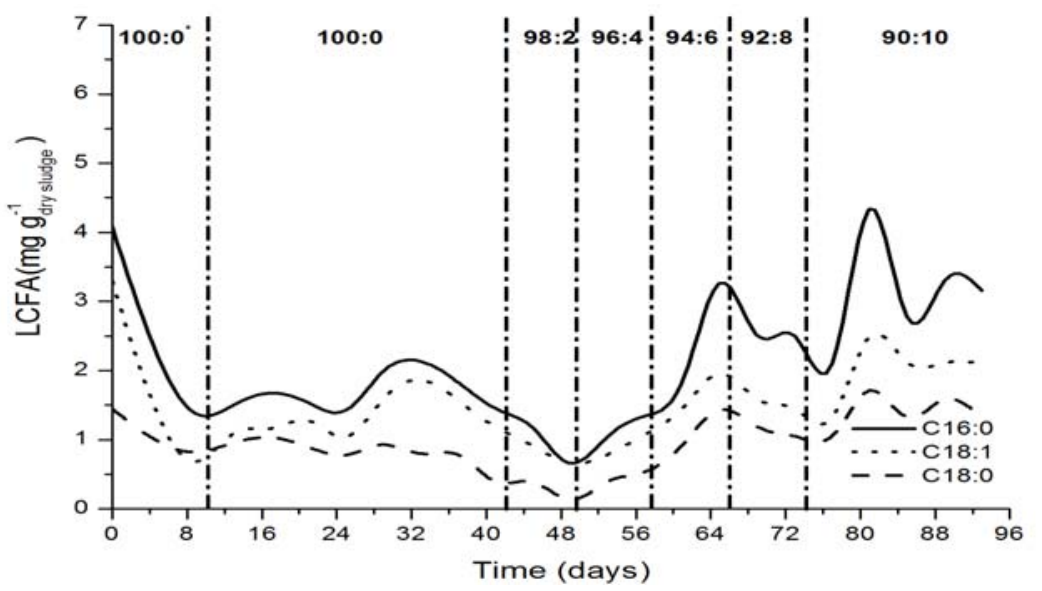

Figure 4. Variation of LCFAs concentration in the effluent in co-digestion

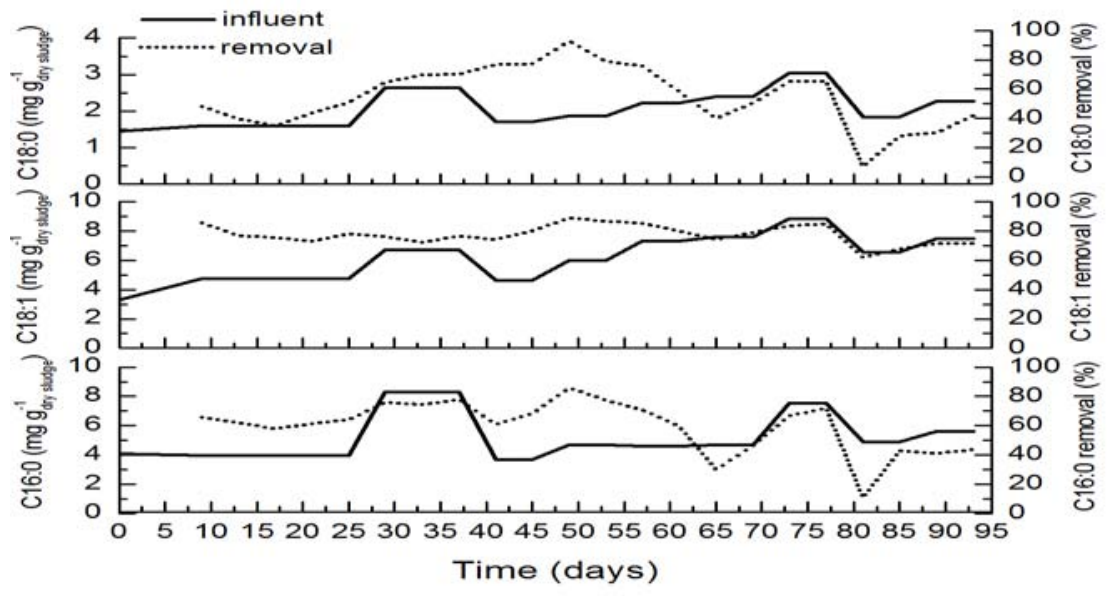

Figure 5. LCFAs removal during anaerobic co-digestion

Although, the significant variations in LCFAs reduction during studied period was observed, the biogas production and methane yield increased with higher addition of GTW. It can be explain by the fact that LCFAs were present at concentration below the ranges for which inhibition of anaerobic digestion has been reported.

\section{CONCLUSIONS}

In this study anaerobic co-digestion of waste from grease traps and sewage sludge was successfully performed in laboratory continuous digestion test. It was found that co-digestion of sewage sludge and GTW improved both biogas production and methane content. Grease trap waste addition of $10 \%$ of feed VS increased the biogas production by $16 \%$ as well as methane concentration $(72 \%$ of biogas) compared to the period when reactor was feed only with sewage sludge. Moreover, the addition of GTW to the anaerobic digestion of sewage sludge increased organic matter removal.

Although, the significant variations in LCFAs reduction during experiment was observed, the biogas production and methane yield increased with higher addition of GTW.

It is also possible that a longer study period would have allowed for more biomass adaptation and restoration of higher methane production.

These results could provide valuable information for future experiments on the application of another biodegradable waste to increase the biogas production by co-digestion process. 


\section{ACKNOWLEDGMENT}

The authors would like to thank to Krzysztof Fijalkowski and Iwona Kupich for the technical assistance provided in the gas chromatography analysis. The study was supported by the Polish Ministry of Science and Higher Education, grant No. R14002006/2009. The part of laboratory equipment used in this study was bought within EU structural founds - project WKP 1/1.4.3/2/2005/61/180/365/2006/U

\section{REFERENCES}

Ahring B.K. (1994), Status on science and application of thermophilic anaerobic digestion, Water Sci.Techol., 30(12), 241-249.

Alves M.M., Mota Vieira J.A., Álvares Pereira R.M., Pereira M.A., Mota M. (2001), Effects of Lipids and oleic Acid on Biomass Development in Anaerobic Fixed Bed Reactors. Part II: Oleic acid toxicity and biodegradability, Water Res., 35(1), 264-270.

APHA, (1999), Standard methods for the examination of water and wastewater, $20^{\text {th }}$ edition, Washington, DC.

Broughton M.J., Thiele J.H., Birch E.J., Cohen A. (1998), Anaerobic batch digestion of sheep tallow, Water Res., 32(5), 1423-1428.

Callaghan F.J., Wase D.A.J., Thayanithy K., Foster C.F. (2002), Continuous co-digestion of cattle slurry with fruit and vegetable wastes and chicken manure, Biomass and Bioenergy, 22(1), 71-77.

Casado A.G, Hernández E.J.A, Espinosa P. (1998), Determination of total fatty acid (C8-C22) in sludges by gas chromatography - mass spectrometry, J. Chrom., 826, 49-56.

Davidsson A., Lövstedt C., La Cour Jansen J., Gruvberger C., Aspergen H.(2008), Codigestion of grease trap sludge and sewage sludge, Waste Management, 28, 986-992.

Fernández A., Sánchez A., Font X. (2005), Anaerobic co-digestion of a simulated organic fraction of municipalsolid wastes and fats of animal and vegetable origin, Biochem. Engin. J., 26, 22-28.

Hanaki K., Matsuo T., Nagase M. (1981), Mechanism of inhibition caused by long-chain fatty acids in anaerobic digestion process, Biotechnol. Bioeng., 23, 1591-1610.

Hartmann H., Ahring B.K. (2005), Anaerobic digestion of the organic fraction of municipal solid waste: influence of co-digestion with manure, Water Res., 39, 1543-1552.

Hwu C.S., Tseng S.K., Yuan C.Y., Kulik Z. and Lettinga G. (1998), Biosorption of long-chain fatty acids in UASB treatment process, Water Res, 32(5), 1571-1579.

Koster I.W., Cramer A. (1987), Inhibition of methanogenesis from acetate in granular sludge by longchain fatty acids, Appl. Environ. Microbiol., 53(2), 403-409, 1987.

Lalman J., Bagley D.M. (2000), Anaerobic degradation and inhibitory effects of linoleic acid. Water Res., 34, 4220-4228.

Luste S., Luostarinen S., Sillanpä M. (2008), Effect of pre-treatments on hydrolysis and methane production potentials of byproducts from meat-processing industry, J. Hazard. Mater., 164, 247-255.

Luostarinen S., Luste S., Sillanpää M., (2009), Increased biogas production at wastewater treatment plants through co-digestion of sewage sludge with grease trap sludge from a meat processing plant, Bioresour. Technol., 100, 79-85.

Malta-Alvarez J., Mace S., Llabres P. (2000), Anaerobic digestion of organic solid wastes. An overview of research achievements and perspective, Bioresour. Technol., 74, 3-16.

Nielsen H.B. and Ahring B.K. (2006), Responses of the biogas process to pulses of oleate in reactors treating mixtures of cattle and pig manure, Biotechnol. Bioeng., 95, 96-105.

Palatsi J., Laureni M., Andrés M.V., Flotats X., Nielsen H.B. (2009), Angelidaki I., Strategies for recovering inhibition caused by long chain fatty acids on anaerobic thermophilic biogas reactors, Bioresour. Technol., 100, 4588-4596.

Pereira M.A., Sousa D.Z., Mota M., Alves M.M. (2004), Mineralization of LCFA associated to anaerobic sludge: kinetics, transport limitations, enhancement of methanogenic activity and effect of VFA, Biotechnol. Bioeng., 88 (4), 502-511.

Pereira M.A., Pires O.C., Mota M., Alves M.M. (2005), Anaerobic biodegradation of oleic and palmitic acids: evidence of mass transfer limitations caused by long chain fatty acid accumulation onto the anaerobic sludge, Biotechnol. Bioeng., 92, 15-23.

Rinzema A., Boone M., Van Knippenberg K., Lettiga G. (1994), Bactericidal effect of long chain fatty acids in anaerobic digestion, Water Environ. Res., 66, 40-49. 